\title{
PODCAST WITH PEER ASSISTED \\ LEARNING TO DEVELOP EFL LEARNERS LISTENING COMPREHENSION AND MOTIVATION
}

\author{
Shofiyatul Huriyah ${ }^{1}$ \\ Baturaja University, Sumatera Selatan, Indonesia \\ Shofiyatulhuriyah@unbara.ac.id \\ Emilia Contessa ${ }^{2}$ \\ Baturaja University, Sumatera Selatan, Indonesia \\ emilia@fkip.unbara.ac.id
}

\begin{abstract}
This study was aimed at investigating the effects of Podcast with Peer Assisted Learning in the EFL listening classroom. In conducting this research, preexperimental design was used. The sample of this study was selected by using simple random sampling involving 27 students as the sample. The data collected were analyzed by using t-test (paired sample t-test) and percentage for two questionnaires, students' motivation and perception. The result showed that (a) there was a significant difference in listening comprehension achievement before and after being taught by using Podcast with Peer Assisted Learning where t-obtained was 8.921 and the significance value was 0.000 which less than 0.05 . On the basis of this result, it can be inferred that listening comprehension achievement of students before and after teaching by using podcast with peer-assisted learning was substantially improved. (b) The percentage score for learning motivation from the students was $(55.6 \%)$ in high level, moderate $29.6 \%$ and low level was $(5 \%)$. This score was considered students have high level of learning motivation. (c) most of the students gave positive perceptions on the use podcast with peer assisted learning in listening classroom. It can be concluded that teaching using podcast with peer assisted learning can develop the students listening comprehension achievement.
\end{abstract}

Keywords : Peer Assisted Learning, Listening Comprehension, Motivation

\section{INTRODUCTION}

1.1 Background of the Study

As a foreign language, in order to make communication work well, learners have to be able to understand what people say to them in English. If they do not consider the speech of their opponents and they neglect to listen and do not respond properly, the goals of communication will not be accomplished. Listening has been called the overlooked capacity for a decade, among four language abilities, listening, speaking, reading and writing, (Tomkins \& Hoskisson 1995). In relation to three cognitive processing stages, expectations, parsing and usage, Anderson (1995) suggested listening comprehension problems. Perception refers to keeping attention to spoken input, decoding means encoding the input to construct coherent short-term memory representation, and using context information to interpret the input for storage utilization issues. First, learners do not remember words they know in the awareness process, neglect the next part when thinking about meaning, cannot chunk streams of 
speech, miss the beginning of text, and concentrate too hard.

Second, Goh (2000) discovered in the parsing stage that listeners easily forget what is heard, are unable to construct a mental representation of words heard, and because of potential problems, they do not understand subsequent sections of feedback. Third, they understand the terms but not the intended message at the use stage, and are uncertain about the main ideas in the message.

According to Saricoban (1995), there are some reasons why the students have difficulties in listening comprehension, such as (1) they lack pronunciation mastery so that it is hard for them to discriminate sounds, (2) they lack familiarity with stress, intonation and discourse, features that can cause them some problems when predicting what will be said, (3) they lack vocabulary mastery so that they don't understand the words they were listening to and (4) listening lesson were not interesting enough for students to learn because of the teaching method used by their teacher.

Since universities pay more attention to English grammar, reading and speaking, EFL learners have significant problems with English listening comprehension. Listening and speaking skills are not major components of several course books or curricula, and when planning their lessons, teachers do not appear to pay attention to these abilities. Many educators take it for granted and believe it will occur naturally throughout the language learning process. Persulessy (1988:50) claimed that the feeling among language teachers that this ability is immediately acquired by the learner as he learns to speak the language is one of the reasons for the belief that listening is an ability that appears to be overlooked. Most teachers often believe listening is synonymous to breathing automatic.

From researchers' observation and experience of teaching the EFL listening skill. In this class, several students performed poorly. Since they did not understand the spoken content of the classes, they were unable to understand natural spoken English delivered at normal pace. Such students also lose all confidence. They have had attention problems for a long time. Even other instructors who were teaching the same course to different groups found this problem. In many other nations, the same problem has also been found (Buck, 2001 and Hayati, 2010). The findings of these research have shown that listeners from different language backgrounds have problems listening to a foreign language. Goh (2000) reported the difficulty of understanding for learners: students faced issues with the comprehension of common terms. They explained that while they were familiar with certain words, they were unable to instantly recall their meaning.Even though they were familiar with the literal sense of words, they also showed difficulty interpreting the intended message. The teacher needs creative teaching methods in this situation to make the students interested in learning to listen. Brown (2001) states that a classroom technique has a great chance for success if it give some beneficial feedback to the students. The students engage in the course because it is enjoyable, interesting, challenging and not because their instructor wants information from the reward of the course. So it will certainly inspire them to enter the listening course by offering some authentic listening materials.

The advancement of information technology has contributed to rapid 
change in the implementation of educational and teaching technologies. In an educational situation, teachers do not simply rely on advanced educational technologies to effectively perform teaching; they do need effective multimedia materials. The materials can meet the needs and wants of the diverse experiences of learners in different settings by using powerful multimedia materials (Tomlinson, 1998). Some functionality that can promote language learning should be integrated into materials to build effective multimedia materials. These can include presentation formats for multimedia and target language proficiency for learners.

Today, as the most advanced messaging device used by billions of people around the world, the internet can help teachers easily provide their students with authentic listening materials. Each student may be asked by the instructor to find an activity they like, so that they can enjoy learning EFL and not feel stressed. In addition, these exercises will make learners more able to learn listening skill. Educational podcasts are one of the apps that might help students develop their listening capacity. A Podcast is an app that uses a device or a modern Android cell phone to be downloaded from the internet. In English, they have several series and several different subjects. The students can easily pick any series or subject they want after downloading the application and they can then listen and watch without any pressure whenever they want (Al Qasim \& Al Fada, 2013). The implementation of Podcasts with Peer-Assisted Learning into English classes could enhance EFL learners' listening skills. This program is suitable for learners, who mostly still have difficulties with listening comprehension.

\section{LITERATURE REVIEW}

2.1 Listening Comprehension
Brown (2002, p.118) describes listening as the unseen, inaudible mechanism of internalizing the meaning conveyed to the ear and brain by the auditory signal. A spoken or written response from the students is the result of listening, which again suggests correct or incorrect auditory processing. It implies that listening is a process for distinguishing sounds, recognizing phrases, assisting speakers and eliminating problems. According to Johan et.al (2015) listening is a subject that requires a high enough concentration. In understanding listening, it is necessary to have skill in understanding each word or sentence uttered by native speaker snowing and assessing what you can like, appreciate and respond emotionally.

Comprehension is sometimes regarded as the aim of listening in the first order, the listener's highest priority, and often the primary objective of listening. According to Block and Presley (2002), understanding is described as a complex process involving the mind of the reader or listener and the language of the text that is read or heard in particular, as well as the social meaning of situations. In addition, Mandleson and Rubin (1995, p.13) describe that the process of receiving, attending and assigning meaning to aural information is listening comprehension. In addition, Nelson and Pearson (1994, p.70) communicate listening is more than just hearing a message since what we hear through our ears is at least activated by the listening process. Nerves send to our brain these sensations. Then consider whether we are going to take care of the stimuli or ignore them, which of many meanings may be assign to it, and whether will store it in short term or long term memory. 
Richards (2008) presents two forms of listening systems, top-down and bottom-up processing. In recognizing the context of a message, top down processing refers to the use of background information. Whereas bottom up processing begins from language to meaning, top down processing goes from meaning to language. Prior knowledge about the subject, situational or contextual knowledge, or information in the form of "schemata" or "scripts" plans about the overall structure of events and the relationships between them may be the background knowledge needed for topdown processing.

This method determines the meaning of linguistic elements in an order from the smallest linguistic unit such as phonemes, sentences, phrases to the largest such as full texts from the bottom up method derived from linguistic information.

In order to create meaning, learners rely on the sounds, words and grammar in the text. This is the method. On the other hand, top-down interpretation requires students to listen with their prior knowledge of the subject, context and type of text, as well as language knowledge to reconstruct the meaning using clues. This knowledge of the context stimulates a collection of perceptions that assist the listener to perceive what is heard and predict what will come next. Predictions can come out of the listening practices. It begins by providing some clues to the students, such as key words, images, or even silent videos. Students should be given some opportunities to predict the subject, situation, or what will be next in the next step.

\subsection{Podcast}

"Podcasts can be defined as" audio or video broadcasts online containing such a Simple Syndication (RSS) feed that allow users to subscribe to the podcast "(O'Bryan \& Hegelheimer, 2007 , p. 165). Podcasts can be defined as" online When subscribed, when new episodes are released, podcast programs can be downloaded to the user's device or portable media player automatically. One of the two primary potential uses for podcasting described in Rosell-Aguilar's taxonomy (2007) is the use of existing resources. Existing podcast resources for language learning can be further divided into two main categories. The first is content created by native speakers for the consumption of native speakers, such as news podcasts released by broadcast media. The second category is teaching content created for language learning. Rosell-Aguilar (2007) sub classified this category into complete courses and supporting materials either for a particular audience or for independent learners. In order to have target language input, the above subgroup of tools supporting materials for independent learning can arguably be most readily used by classroom teachers.

ELT podcasts are particularly suitable for supporting the interest of students in listening to English and presenting them to native speakers (Rost, Person, P.,2006:119). Stanley (2006:2) points out that podcasts give students a large variety of opportunities for additional listening, both inside and outside the classroom: "It is an interesting choice for language teachers to supplement scripted and stilted textbook listening with the real life genuine conversations that you can hear on many podcasts. Carefully chosen, excerpts can carry a variety of different voices and varieties of English into the classroom." ELT podcasts are a tool that 
develops listening abilities and it is possible to inspire students to use appropriate techniques. When it introduces business language and phrases through genuine business scenarios and dialogues that go along with them, it also acts as a resource provider. Thus, by downloading audio files and motivating students to listen to them, podcasts may be used to supplement classroom teaching. For instructors, podcasting is also a perfect way to offer listening material to their students. They can organize homework tasks, document book narratives to read along with beginning readers, or create foreign language lessons that students can study at their own pace.

\subsection{Peer Assisted Learning}

Peer-assisted learning is a classroom program designed to increase and enhance listening skills, especially for poorer listeners, such as fluency and listening comprehension. Furthermore, the PAL approach focuses on interacting with peer groups or partners that provide opportunities for advantageous social experiences. Peer facilitated learning has been one of several educational methods, according to Kawas (2016), can assist learning in many higher education institutes. Peer assisted learning has been described as individuals from similar social groups who are not skilled teachers who support each other by teaching to learn and learn themselves. The key points to note are that those who encourage their peers to learn have less detailed subject matter knowledge, but they are from the learners' related social groups and not generally from the same course or year of study. The rationale of peer assisted learning lies in the fact that learners, whether tutors or tutors, share a common knowledge base and learning experience that enables peer tutors to use language that their learners understand to clarify concepts at an acceptable level.

According to Toping and Ehly (2009, p.2), PAL's archaic interpretation considered the peer helper as a surrogate tutor, from instructor to peer helper to tutee, in a linear model of information transmission. Traditionally, there was an expectation that helpers (i.e. those who were more like trained teachers) should be among the best students. However, under stimulating for the helper, who was unlikely to learn cognitively from the experiences, the difference in levels of skill and interest in such a case may be shown. Later, it was realized that the relationship between the peer who assisted was qualitatively different from that between a skill teacher and a child or young person, which included various advantages and disadvantages. Recently, there has been more interest in the implementation of associates whose skills are similar to those supported, such that in their cooperative tasks, all members of the pair find many cognitive challenges. In these cases, the helper was supposed to learn by teaching and was also a more proximate and credible model.

Peer learning refer to a learning method that uses an accomplished pair students with low-ability students in the classroom and get supervision from the teacher. There was guiding and mentoring term used by the teacher for the activity. According Toping and Ehly (2009, p. 1) in some peer assisted learning methods, peer helper are more intensively and consciously active in the helping role than in other method. One of the advantages of this method can also develop higher student ability and more easily understood by lower student ability. According to Tariq (2005), peer assisted learning also encouraged the students to become more active and 
independent learners, assuming greater responsibility for their own learning as well as that of peers.

\subsection{Motivation}

Motivation to learn is a three word expression that connects motivation and learning, each of which has distinct meanings but is closely related (Karaoglu, 2008). A psychological condition that encourages students to learn with pleasure and honesty is incentive to learn. Students will feel satisfied and excited about learning with high motivation to learn, so that it can impact the quality of the learning process and the learning outcomes of the students themselves. The motivation for learning that arises in learners is due to their values or the motivation they get to achieve the expected results.

Kubanyiova (2006) states that standard of classroom learning performance does not depend on the cognitive skills of students, but is also affected by dynamic motivational and affective factors. Highly motivated students will be able to put more resources into learning English, while low-motivated students will not be ready to display great interest in learning. In addition, Dornyei (2001) explains that it is assumed that motivation is responsible for "why people decide to do something, how long they are able to continue the practice and how much they can follow it."

\section{Research Method}

\subsection{Method of the Study}

In this study, the researchers used pre-experimental design. Preexperimental design involved group of pre-test and post-test. The researchers used one class to do a research in giving pre-test, treatment and post-test.
3.2 Subject of the Study

The population of this study was 64 students of English Education Study Program from the second, fourth, and sixth semester. In conducting this study, a simple random sampling was used. Creswell (2012, p.144) defines the analysis is equally likely to be chosen and the research is comparable. The probability of the selection of a member of the population is the selection of other members of the population does not affect. 27 students chosen were randomly and assigned into one group, experimental class.

\subsection{Data Collection}

The data in this study were obtained using a questionnaire and a listening comprehension test. Two kinds of ready made questionnaires were used in this study. First, it was used for classifying the participants into category of motivation. Then the second questionnaire was used to obtain the students' perception on the use of podcast with peer assisted learning. Meanwhile, to obtain the students' achievement, a listening comprehension test was used in pretest and posttest. The listening comprehension test consisted of 30 multiple choice questions to collect information that measured the reliability and validity of the test before it was administered to the study sample.After analyzing the validity of the test, the researchers check the reliability of test by using Cronbach Alpha. According to Wallen and Fraenkel (2009), a maxim for study purposes is that reliability should be at least 0.70 and higher in advance. This means that the test would be correct since it is greater than 0.70 and can be used in real research. Futhermore, it was found that the reliability of listening comprehension 
test was 0.867 . From the result, it can be seen that the tests were reliable.

\subsection{Data Analysis}

After getting the data of pre-test and post-test, the researchers began to analyzed the data by used matched t-test to get the result of the investigation, in order to find out the difference scores on students' listening comprehension achievement after being taught using podcast with peer assisted learning. The analyze data of questionnaire classified based on distribution score of students motivation. Meanwhile, percentage was used to find out the effect of using podcast with peer assisted learning towards students 'motivation. In addition, normality and homogenous test were used before doing the statistical analysis in this study. Percentage analysis also used to find out the students' perception on the use podcast with peer assisted learning in listening classroom.

\section{RESULTS AND DISCUSSION}

\subsection{Descriptive Analysis}

In listening comprehension, the result of the mean score pretest was 52.84, meanwhile the mean score of posttest was 63.95. It means that podcast with peer assisted learning could improve the students' listening comprehension achievement. The percentage of students' score distribution could be seen in table 1 below.

Table 1. The Score Distribution of Pretest and Posttest

\begin{tabular}{|c|c|c|c|}
\hline \multirow{2}{*}{$\begin{array}{c}\text { Score } \\
\text { Interval }\end{array}$} & \multirow[t]{2}{*}{ Category } & \multicolumn{2}{|c|}{ Experimental Group } \\
\hline & & Pretest & Posttest \\
\hline $86-100$ & Very good & - & $7(25.9 \%)$ \\
\hline $76-85$ & Good & $2 \quad(7.4 \%)$ & $3(11.1 \%)$ \\
\hline $56-75$ & Average & $10(37 \%)$ & $14(51.9 \%)$ \\
\hline \multirow[t]{3}{*}{$<56$} & Poor & $15(55.6 \%)$ & $3(11.1 \%)$ \\
\hline & & 27 & 27 \\
\hline & Total & $(100 \%)$ & $(100 \%)$ \\
\hline
\end{tabular}

From the table above, it was found that before the teaching by using podcast peer with assisted learning, there was no student in very good category and there was only 2 students in good category, but after being taught by podcast with peer assisted learning, it was found that there were 7 students $(25.9 \%)$ in very good category and 3 students $(11.1 \%)$ in good category.

\subsection{Statistical Analysis}

In this study the researchers used paired sample t-test to see the mean difference within the groups before and after treatment. In listening comprehension, it was found that the mean difference between pretest and posttest score was 11.111 and the outcome was 8,921 and the amount of significance was 0,000 . Based on this result, it can be inferred that before and after the teaching using podcast with peer-assisted learning, there was a substantial difference in the listening comprehension achievement of students.

Next is statistical analysis of students' motivation. In order to assess the degree and form of motivation to learn from the subjects, a five-point Likert scale was used. The degree of agreement anddisagreement based on the parameters in Table 2 below was defined by the scale used in the questionnaire.

Table 2. Mean Range Interpretation

\begin{tabular}{c|c}
\hline Mean Range & Interpretation \\
\hline $3.68-5.00$ & High Degree of motivation \\
\hline $2.34-3.67$ & $\begin{array}{c}\text { Moderate degree of } \\
\text { motivation }\end{array}$ \\
\hline $1.00-2.33$ & Low degree of motivation \\
\hline
\end{tabular}

The findings present the results concerning the students' motivation for learning Podcast with assisted learning. The table presents the motivation 
statement items, their mean scores, and their related level of motivation .

The results mean score students' rating motivation can be classified into motivation level percentage in the table below.

Table 3. Students' Percentage Motivation Level

\begin{tabular}{ccc}
\hline $\begin{array}{c}\text { Mean } \\
\text { Range }\end{array}$ & Interpretation & Percentage \\
\hline $\mathbf{3 . 6 8}-\mathbf{5 . 0 0}$ & $\begin{array}{c}\text { High Degree } \\
\text { of motivation }\end{array}$ & $15(55.5 \%)$ \\
$\mathbf{2 . 3 4}-\mathbf{3 . 6 7}$ & $\begin{array}{c}\text { Moderate } \\
\text { degree of } \\
\text { motivation }\end{array}$ & $6(22.3 \%)$ \\
$\mathbf{1 . 0 0}-\mathbf{2 . 3 3}$ & $\begin{array}{c}\text { Low degree of } \\
\text { motivation }\end{array}$ & $4(14.8 \%)$ \\
\hline
\end{tabular}

The mean scores in motivation questionnaire show that the students of English education study program have a high level of motivation after being taught by using podcast with peer assisted learning. The percentage score for learning motivation from the students of was $(55.6 \%)$ in high level motivation, moderate $22.3 \%$ and low level was $(14.8 \%)$. This score wass considered high level of learning motivation. In other words, the students are highly motivated in listening classroom by using podcast with peer assisted learning.

For further information of the result of this study, the questionnaire was distributed toward the students' perception using podcast with peer assisted learning in listening classroom. The result of this study showed that most of 27 students agree that listening with podcast can make the situation enjoy learning listening. Students showed their interest in learning listening. They mostly gave positive response in implementing podcast with peer assisted learning. The description of students' higher percentage from students' questionnaire could be seen in chart below
Chart 1. Students' Perceptions on the Use Peer Assisted Learning in Listening Classroom

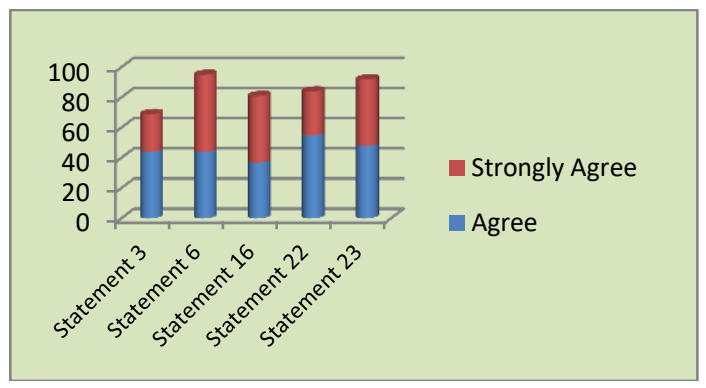

The questionnaires result showed that $62 \%$ students want podcast be implemented in the classroom, $96 \%$ feel that Podcast with peer assisted learning was fun and enjoyable since they can learn anywhere they like or outside of the classroom, $81 \%$ found that Podcast with peer assisted learning motivate them to learn listening. In addition, 85\% students agree podcast with peer assisted learning strategy was also successfully encouraging the students to remember many word even increase their vocabulary $(85 \%)$ and $92 \%$ students agree listening to podcast can improve their pronunciation.

\subsection{Interpretation}

Based on the result of the research, the mean score obtained by pretest and posttest result, it was understood that post test was better than pre test. This progress is probably caused by podcast with peer assisted learning which provides audio and visual, that allow the students to access more information when listening. They could listen and see what was happening at the same time. They were able to create words and pictures that helped them analyzed their own use of the language or even learn new vocabulary.

The result of this study showed that students have better understanding the difficult words easily by looking at video in podcast. Using podcast means the 
teacher invite the students to enjoy in learning English, Students pay attention to the course, arouse curiosity during the lecture, and develop a good learning environment.

By applying this strategy peer assisted learning the students enjoyed, they were motivated to learn actively. They were conditioned to be more active in the class by working in group. they could understand the meaning from the podcast freely by their own interpretations. They also got a new situation in learning listening comprehension that help them to avoid boredom. On the other hand, peer assisted learning beneficial for students in listening classroom. For different groups of students with varying learning skills in the class, the teacher did not have to organize additional tasks. Partner study has given teachers with a way to structure learning experiences that meet much of the EFL students ' specific learning needs.

Motivation and learning strategies play an important role in the process of language learning, which can affect the outcome of language learning. The percentage analysis of students' perceptions on the use podcast with peer assisted learning in listening classroom confirmed that the strategy could improve students listening comprehension achievement.

\section{CONCLUSION}

Based on the results of the data analysis and interpretations, three conclusions are presented. First, based on the data analysis showed that there was a significant difference in listening comprehension achievement between pre test and post test of the students English education study program. Post-test students achieved a better performance in listening comprehension than pre-test students. Second, based on the data analyses showed that all of the mean scores in motivation questionnaire indicate that most of the students of English education study program have a high degree of motivation after being taught by using podcast with peer assisted learning. And finally the students perceptions on the use podcast with peer assisted learning in their classroom gave positive responses to the statement about activities they did while learning listening comprehension.

\section{REFERENCES}

Al Qasim, N., \& Al Fadda, H. (2013). From CALL to MALL: The effectiveness of Podcast on EFL higher education students' listening comprehension. English

Language Teaching, 6(9), 30-41

Buck, G. (2001). Assessing Listening. Cambridge: Cambridge University Press.

Brown,H.D.(2011). Language assessment:Principles and classroom practice.

New York : Pearson Education, Inc.

Brown, H.D. (2002). Strategies for success. New York : Longman.

Cresswell, J.W. (2012). Educational research; planning, conducting, and evaluating

quantitative and qualitative research (4th edition). New York: Pearson.

Dornyei, Z. (2001). Teaching and researching motivation. England: Pearson Education. 
language listening. San Diego,

Fraenkel,J.R \& Wallen, N.E (2009). How to Design and Evaluate Research in Education $\left(7^{\text {th }} \mathrm{ed}\right)$. New York. McGraw-hill

Goh, C.C.M. (2000). A cognitive perspective on language learners' listening comprehension problems. System, 28:55-75

Johan, et.al (2015). Gangguann reseptif mahasiswa dalam menjawab soal-soal listening:

Suatu kajian neuropragmatik. Basis Journal. 1 (2), (33-39) at

<http://ejournal.upbatam.ac.id/in dex.php/basis/article/view/550>. Date accessed:

27 sep. 2020.

Kawas, S.A. (2017). Peer-assisted learning associated with team-based learning in dental education.

Professions education, 3, 38-43.

Kubanyiova, M. (2006). Developing a motivational teaching practice EFL teachers

Slovakia: Challenges of promoting teacher change in EFL context. 10(5), 1-17.

TESL-EJ,

McMaster, K. (2008). Implementing evidence based practices with at-risk readers:

Effects of PALS for kindergarten English learners. Asheville : NC.

Mendleshohn, D.J. \& Rubin, J. (1995). A guide for the teaching of second
CA : Dominie Press.

Nelson, P.E. \& Pearson J.C. (1994). Understanding and sharing: An introduction

to speech communication. New

York : WCB Brown\& Benchmark Publishsers.

O'Bryan, A., \& Hegelheimer, V. (2007). Integrating CALL into the classroom: The role

of podcasting in an ESL listening strategies course. ReCALL, 19(2), 162180.

http://dx.doi.org/10.1017/S09583 44007000523

Richards, J. C. (2008). Teaching listening and speaking from Theory to practice. New York: Cambridge University Press. Retrieved from http://www.cambridge.org/elt/tea cher-supprt/pdf/Richards- Teaching Listening-

Speaking.pdf.

Rosell-Aguilar, F. (2009). Podcasting for language learning: Re-examining the potential. In the next generation: social networking and online collaboration in foreign language learning, 13-34. Ed. by L. Lomicka \& G. Lord. Callico, Texas:

San Marco.

Saricoban, Arif. (1995). The teaching of listening. The Internet TESL Journal. 5.(12): $1 . \quad$ Retrieved from http://iteslj.org/articles/Saricoban_listeni ng.html 
Rosell, Aguilar, F. (2007). Top of the pods - in search of a podcasting "podagogy" for

language learning. Computer Assisted Language Learning, 20(5), 471492.

http://dx.doi.org/10.1080/095882 20701746047

Rost, M. (1991). Listening in action: Activities for developing listening in language teaching. Englewood Cliffs, NJ: Prentice Hall.

Stanley, G. (2006). Podcasting: Audio on the internet comes of age. TESL-EJ, 9(4),
Tariq, V.N. (2005). Introduction and evaluation of peer-assisted learning in first year dergraduate bioscience. BEEJ, 6(8), 21-39.

Tompkins, G. E. \& Hoskisson, K. 1995. Language Arts: Contents and Teaching Strategies (3rd ed.). New Jersey: Prentice Hall.

Tomlinson, B. (1998). Materials development in languagee teaching. Cambridge: Cambridge University Press.

Toping, K \& Ehly, S. (2009). Peer Assisted Learning. Routledge, New York:USA. 